Article

\title{
The Subtle Dynamics of Power Struggles in Tunisia: Local media since the Arab Uprisings
}

\author{
Noah Bassil * and Nourhan Kassem \\ School of Social Sciences, Macquarie University, Australia; E-Mails: noah.bassil@mq.edu.au (N.B.), \\ nourhan.kassem@gcsc.uni-giessen.de (N.K.) \\ * Corresponding author
}

Submitted: 29 April 2021 | Accepted: 4 November 2021 | Published: 17 December 2021

\begin{abstract}
This article contributes to the analysis of local media and democratic transformation in Tunisia since the Arab Uprisings. It aims to assess the extent to which pluralism, freedom of expression, and participation-central tenets of democratisation-are evident at the local level. Tunisian local media, unlike the national media, is relatively free of governmental control. Local media is also decentralised. It is this autonomy from the government which makes the analysis of local media fundamentally important for understanding politics in Tunisia. While national media is linked to the most powerful elements in the country, the diversity of voices within the media at the local level provides an opportunity to grasp the grievances, struggles, and agency of people in Tunisia, especially the most marginalised communities. This article will detail the changes in the media landscape, especially for local media, in Tunisia and connect our analysis of local media to better understand the Tunisia that has developed between dictatorship and democracy and the extent that the fledgling Tunisian democracy can withstand its most recent test.
\end{abstract}

\section{Keywords}

Arab uprisings; democratisation; local media; MENA; proximity journalism; Tunisian media

\section{Issue}

This article is part of the issue "Ten Years after the Arab Uprisings: Beyond Media and Liberation," edited by Hanan Badr (Gulf University for Science and Technology, Kuwait) and Lena-Maria Möller (Max Planck Institute for Comparative and International Private Law, Germany).

(C) 2021 by the authors; licensee Cogitatio (Lisbon, Portugal). This article is licensed under a Creative Commons Attribution 4.0 International License (CC BY).

\section{Introduction}

Tunisia's reputation as the only Arab state to make genuine headway towards democracy in the 10 years following the Arab Uprisings appeared to have been invalidated when President Kais Saied, on July 25 2021, evoked Article 80 of the Constitution, sacked the prime minister, and suspended parliament. Since Saied's capture of government, there have been mass rallies across the country supporting the President's actions. Saied's actions are seen by many in the country as necessary to address critical problems associated with the political stalemate that has hampered the democratic transition. A nationwide poll conducted by Emrhod consulting in the days immediately following the takeover highlighted the popularity of the President and his decision to assume temporary unilateral power (Abueish, 2021). The President's actions and the popular response from Tunisians, given the chaotic nature of politics and the economic and health crises engulfing Tunisia since the emergence of Covid-19, are not entirely unsurprising.

The fears that Tunisia, a country of 11,8 million people, would slide into dictatorship heightened even further after security forces stormed and shut down Al Jazeera's office in Tunis on July 26, 2021. At the time this article was written on October 26, 2021, the government had given no reasons for the raid on Al Jazeera or for the fact that Al Jazeera's Tunis office still remained 
closed, with its equipment confiscated and reporters working remotely. The Syndicate National des Journalists Tunisiens, an independent civil society group set up following the 2011 revolution, reported a worrying rise in intimidation and violence against journalists since Saied's takeover. It is not surprising that these attacks against the media are raising questions about Saied's commitment to democracy. Media freedom and the independence of the press is widely agreed upon as foundations upon which democratic societies stand (Keane, 1991, 2013; Mughan \& Gunther, 2000).

While, as Dennis and Snyder (1998) have expressed that the media plays a vital role in promoting democratic societies, Bogart (1998, p. 5) makes the crucial point that "any answer to the question of whether media serve democracy must be qualified: which media, and among what parts of the public?" In this article, we aim to look at local media as part of Tunisia's democratic transition. Much has been written about the media in Tunisia since the fall of the dictatorship, including the common theme that the post-authoritarian period has been marked by gains and challenges for freedom of expression and plurality (El-Issawi, 2012; Miladi, 2021). As expected, much of this focus has been on national politics and the national and international media. Without ignoring the importance of the national, and for that matter, the international, contexts, we focus our attention on the under-researched local community media that has emerged in the period since the revolution. Our major research question is what insight about change in a transitional democracy does an analysis of local media provide for researchers' understanding of politics in Tunisia, and how does researching local media inform our understanding of democratic change in a country such as Tunisia where freedoms of expression have long been denied by colonialism and dictatorships? This article aims to fill some of the deficit in the literature on local media. Drawing on content from four local media outlets in regions of Tunisia that are marginalised and under-represented, both politically and as producers of media, we will aim to contribute to a better understanding of the role of local media in a country transitioning from dictatorship to democracy.

In this article, we will detail the change in the media landscape, especially for local media, in Tunisia. Then we will aim to connect our analysis of local media to the political struggles that have shaped Tunisia since the fall of Ben Ali. In this way, we hope to provide new insights from the local level of politics and society to better help understand the Tunisia that has developed between dictatorship and democracy and the extent that the fledgling Tunisian democracy can withstand its most recent test.

\section{Local Media, Politics, and Tunisia Since the Revolution}

In the wake of the revolution, much has been written about social media and its impact on the Arab world
(Zayani, 2015, pp. 7-8). Global and national media in Tunisia have also been a subject of much interest to scholars (Ghazali, 2015, pp. 6-22). Local media remains less researched, as Kristy Hess and Lisa Waller argue, because there is little appetite for research on the relationship between politics and media at the local level $(2016$, p. 8$)$. Where there is interest in the local media, it is largely in the developed world where local media is under pressure from economic and technological changes and where the loss of local media is seen to be detrimental to democracy and social cohesion (Hayes \& Lawless, 2018; Nielsen, 2015). In Tunisia, as this article will show, despite the existence of many of the same economic and technological pressures facing local media elsewhere, the revolution provided an opportunity for local media to emerge from decades of governmental control and shape the post-revolutionary outcomes (Voltmer, 2013). Yet, few studies have focused on local media in Tunisia.

In Routledge Companion to Local Media and Journalism, published in 2020, there is not one mention of Tunisia. Nouredinne Miladi's excellent account of media in Tunisia after the revolution has little to say about local media (2021, pp. 276-284). As far as we can tell, there is no research published in English that has undertaken empirical research of the content of local media for a better understanding of the changes that have occurred in the regional, especially marginalised regions, of that country.

This article applies observation and critical review of four local media formats that have emerged in the period since the Arab Uprisings. Utilising survey material from Open Sigma (2017), we were able to establish the popularity of local media in regional parts of Tunisia. The media that were analysed were Nefzwa Journal, Radio Nefzawa, Radio Gafsa, and Radio Mines FM. Nefzwa Journal and Radio Nefzawa were chosen because they are representative of the Amazigh, who are considered a significant ethnic minority in Tunisia. Radio Gafsa and Radio Mines FM are both located in Gafsa. Radio Gafsa is a public radio station, while Radio Mines FM receives funding from UNESCO and emerged after the revolution as a voice from, and for, the mining communities of Gafsa. Gafsa is in central-western Tunisia, where mining communities have challenged poor working conditions, underdevelopment, and poverty. In 2008, an uprising in Gafsa was brutally suppressed by the government of Ben Ali. These issues remain of major concern for the people of Gafsa. We collected primary evidence from the four local media above. We also collected 862 programs and stories for analysis as part of the research. We used this data to ascertain whether analysis of the content of local media provided offers opportunities to make claims about the changes to Tunisia in the post-revolutionary period. We also utilised a number of locally produced studies of post-revolutionary media in Tunisia written in Arabic (Abou Arief, 2014; Zran \& Sedraoui, 2019). Unlike most research that has focused on the national level, this research aims to 
investigate whether the marginalised and previously silenced regions of Tunisia are now engaged in the national debate and the extent of the democratic effect in regional Tunisia. In addition, we aim to contribute to a more nuanced understanding of the rich diversity and the multiplicity of the Arab world that challenges one-dimensional, homogeneous tropes centred on the incompatibility of Arabs and Muslims with democracy.

\section{Local Media, Democratisation, and Tunisia in the Global Context}

Local media is noted amongst media scholars as pivotal in the development of informed civics and social cohesion (Hayes \& Lawless, 2015; Leupold et al., 2018; Meijer, 2010; Snyder \& Stromberg, 2010). Tunisian Professor of journalism Jemal Zran and Nabil Sedraoui, the manager of local community broadcaster, posit that the term local media is derived from the concept of the local community. Local media is defined as an institution or media broadcasting dedicated to taking "care" of the local community (Zran, \& Sedraoui, 2019, p. 371). Saima Saeed (2009, p. 470), focusing on community media, specifically community radio in India, provides a succinct approach to community media as media that is "produced by the local community in their own language for their own consumption on issues that they themselves deem relevant to their needs." Carpenter et al. (2003), drawing on Laclau and Mouffe (1985), also posit that community media offers an opening for counter-hegemonic discourses to be produced and heard. The common aspect of these positions towards local and community media is that it provides opportunities for local actors and marginal groups to participate in public discourse and potentially influence public opinion and policy-making; both of which are vital ingredients in the development and consolidation of participatory democracy (Cherni, 2014; Zemni, 2021). In the Tunisian case, local media, especially local media in marginalised regions of the country, are vital aspects of the transition from dictatorship and the emergence of a post-dictatorship society. Prior to the fall of Ben Ali, Tunisian media was centrally controlled and managed by the regime. It was "a system of governance, establishing complex and ingenious mechanisms to lock down the space for media and information and to control, with an iron fist, all means of communication, public and private" (Buckley et al., 2013, p. 15). In the peripheral south of the country, Noureddine Miladi explains that the media landscape was not only censored but long has been dominated by media from the richer, more developed coastal areas (2021, p. 269). Miladi, furthermore, emphasises the underlying and pervasive regional divide for any understanding of the politics and culture of Tunisia more broadly.

An informed and engaged polity is a central feature of democratic theory (Hayes \& Lawless, 2018, p. 333), and the media is at the forefront of providing informa- tion and promoting citizen engagement (Voltmer, 2013). Manyozo (2012, pp. 15-20) pointed to three approaches for analysing local community media. The first approach looks at the processes of reporting as well as communicating development in which media constitute the key strategy in public communication, campaigns, and advocacy on and about development issues. The second approach revolves around securing the free flow of information with all it requires for supporting and building the capacity of policies, structures, and sponsorship as means of good governance. The third approach stems from UNESCO's conception of dialogical communication among people and focuses on community-based involvement by which development stakeholders facilitate participatory communication so that they can author development from below.

The importance of studying the impact of transnational and national media is well established, and in the case of the Arab world, the absence of independent media and the democracy deficit have been linked (Springborg, 2007, pp. 235, 237; see also Lynch, 2015). The MENA region continues to lag behind other regions on the World Press Freedom Index. While many Arab countries remain poorly placed in the Index, Tunisia was ranked 74th in the world in 2020, rising almost 100 places in the 10 years since the fall of Ben Ali (Reporters Without Borders, 2021). This improvement for media, and journalists, appeared to mirror the progress towards democratisation in Tunisia compared with the rest of the region where authoritarianism and repression dominate. We are not venturing into the facile arguments that one leads to the other, and to quote a scholar of social media, independent media "does not necessarily spread freedom, nor is it an antidote to tyranny" (Zayani, 2015 , p. 8). However, the fact that pluralistic voices prevail in any society is not irrelevant when determining the extent to which democratisation has progressed. Weak democracies and authoritarian governments are, typically, amongst other features, characterised by the absence of an active press and strict government control of media.

The problems of authoritarianism and media repression that exist in the Arab region should not be decontextualised from wider global trends that undermine democracy, including increased antagonism towards journalists and attacks on the freedom of the media (Kenny, 2019). As Kenny highlights in a study of 91 countries from 1980-2014, the resurgence of authoritarianism and the assault on the media are not an Arab, or even post-colonial, phenomenon even if those issues have a particular history in the Arab world. The study shows that populist movements are responsible for declining media freedom. A 2019 report by Freedom House not only finds that there have been "concerted attempts to throttle the independence of the media sector," they link this trend to declining levels of freedom, especially democratic freedoms (Repucci, 2019). Alongside the government attacks on the media, the amplification of the 
corporatisation of the media and concentration of media ownership, linked to neoliberalism, has had a profound impact on the capacity of the fourth estate to hold elites to account (Phelan, 2014). McChesney (1997, p. 2) views the media as complicit in undermining democracy, claiming that "the wealthier and more powerful the corporate media giants have become, the poorer the prospects for participatory democracy." Renowned scholar of democracy, John Keane, also known for coining the term "refolution" (Keane, 2011) to define the Arab Uprisings when a majority of others were declaring them as revolutionary transformations, has made numerous connections between the role that a pluralistic media has in the defence of democracy (Keane, 2013). John Keane argues that for all of democracy's shortcomings, it is still worthwhile defending, which is a sentiment that many in Tunisia have also expressed in the days and weeks following Kais Saied's takeover of government.

The anxieties that scholars have expressed about the capacity of the media to act as the fourth estate flow down to the level of local or community media as well (Hayes \& Lawless, 2018, p. 323). Since news is sometimes defined as the first draft of history, we could claim that none is more so than local news. Being first on the scene requires proximity and an ear to the ground. Local journalists have both. They are usually members of their communities; they have unparalleled access to and awareness of local issues and events and have built up the trust of many members of their communities. They concentrate on local subjects within their communities. These journalists can have the advantage of being able to uncover events that are mostly neglected on the national level due to a lack of accessibility to identify or report them. There is no substitute for this advantage (Akhtar, 2019, p. 8).

While national and global media remain attractive to large corporations and private equity, local media and news outlets suffer from a different fate. They are rarely profitable, and where they are, they rely mostly on advertising and infotainment rather than on journalism and on reporting on local matters of importance to the community. Nielsen says that local newspapers have been extremely hard hit by the digital revolution as "readership is eroding, advertising declining, and overall revenues plummeting" $(2015$, p. 3$)$. As the Columbia Journalism Review pronounced in 2018, "America's local news has reached its death spiral" (Pope, 2018). The impact of the decline in local media on democracy is also a matter of major concern. Local media is an important element ensuring the honesty of local politicians, business people, and authorities. In a 2003 study, it was found that there was a direct correlation between active local journalism and lower levels of corruption by local elites (Adsera et al., 2003). More so, local media can play a prominent role in promoting local initiatives, health and education outcomes, and can empower marginal groups (Birowo, 2011). In Kevin Howley's view, local or community media "are popular and strategic interven- tions into contemporary media and culture committed to the democratisation of media structures, forms and practices" (2005, p. 2) and cannot be ignored despite the paucity of attention that has paid to media at the subnational level (Howley, 2013).

The implications of the crisis of the media, including the local media, on democracy cannot be overstated. One of the most important arguments that we will make is that while the struggles in Tunisia parallel much of what has been described above, there are aspects of Tunisia's post-2011 political dynamics, some at the national level and at the understudied local level, that push strongly against global and regional trends. Badran et al. (2021) argued that Tunisia is exceptional in the MENA region for opening up media freedom. These dynamics, most specifically at the local level, may provide insight into the extent to which Tunisians have embodied "democracy" despite universal and nationally specific de-democratising pressures that have been pushing against the gains made since the 2011 revolution.

\section{Media in Tunisia Before the Revolution: The Era of the Padlock}

Prior to independence, publications and broadcasts in Arabic, Italian, and French were prevalent (Smati, 2010, p. 13). In the period of French occupation (1881-1956), over 100 newspapers were available in Arabic alongside more than 10 published in French (Miladi, 2021, p. 269; Zran \& Sedraoui, 2019, p. 372). Up until 1911, Miladi informs us that many of these publications were involved in the anti-colonial struggle. In 1911, the colonial government commenced a phase of censorship and control of the media that came to characterise Tunisia for a century. This policy was continued after independence when the government of Habib Bourguiba issued a decree to reinforce its monopoly on broadcasting (Miladi, 2021, pp. 268-269). With Zine El Abidin Ben Ali's ascension to power in 1987, there appeared to be a liberalisation of the media as a number of private media stations came into existence. However, as Zaid (2018) argues, partial privatisation of the media was mostly a transfer of ownership to close associates and members of the regime, especially members of Ben Ali's family (Miladi, 2021, p. 272). What appeared to be the liberalisation of the media was, in fact, the opening up of the media economy to Ben Ali's family members and those closest to the regime, which had the effect of tightening government control of the media.

Despite monopolisation, repression, and censorship, there were a few attempts to establish local community media prior to the revolution. Radio6 was founded in 2007 in Tunis, and Radio Kalima was also established in Tunis the following year. Both broadcasters exerted tremendous effort to develop these platforms. Major topics of discussion were those of citizenship and human rights. The broadcasts were made by political activists and media figures such as Sihem Bensedrine. 
Both platforms were broadcast on the internet amid the absence of any legal, administrative, or financial support. Nevertheless, they faced interference and surveillance, and both broadcasters were banned by the Ben Ali government (Mezghanni, 2015, p. 195).

The other defining feature of Tunisia's media landscape was the regional divide. The paucity of regional media in the interior has been a distinguishing feature of Tunisia, mirroring the uneven development between more affluent coastal regions and the marginalised and impoverished North-West, Central-West, and South-West. The first private regional journal, Al Qanal, was issued in the Bizerta governorate, northeast Tunisia, in 1967. In addition, there were a handful of journals that were issued with partial support from the government to appear to international observers that the Tunisian government encouraged culturally, politically, and regionally diverse journalism. Most of these journals ceased, such as Al Mithaaq which was issued in Sousse, Hadramawt in the same city, besides Chams al Janub in Sfax, Mir'at al Wasat as well as Baraaem al Wasat in Sidi Bouzid, Aljazeera in Djerba, and Al Ithaf in Siliana. These journals were established with limited support and were seldom legalised (Smati, 2010, p. 13). These efforts at establishing local community media failed because they were not supported by the government and lacked the financial resources to remain active (Smati, 2010, p. 15).

In 1977, Monastir broadcasting was established to provide broadcasts to the middle and coastal parts of the country: Tunis, Zaghouan, Nabeul, Sousse, Monastir, Mahdia, and Kairouan. In the period from 1990-1993, three other broadcasters also emerged, with each covering three governorates/states at the same time (Homid, 2012, pp. 100-101). Regardless of the increase in the number of broadcasters, the regime controlled the media to ensure that the news and entertainment produced and communicated in Tunisia served its interests. The peripheries were politically and economically marginal and culturally silenced, not least because of the absence of platforms for locals to raise their voices. The uprisings of 2011 were a moment when the peripheries were not silenced. The following sections of this article aim to show how the changes that have occurred since 2011 have opened up opportunities in regional Tunisia that were denied by the censorship and control of the media by successive colonial and post-colonial governments.

\section{Media in Tunisia After the Revolution}

Even with the events of July-August 2021, it is not inaccurate to claim that Tunisia's record regarding the treatment of journalists and freedom of the press has improved since the fall of the dictatorship. The revolution provided the impetus for the establishment of numerous newspapers, radio broadcasters, and news websites, but as early as 2012, UNESCO reported that due to a problem not unique to Tunisia or the Arab world, the failure to raise sufficient revenues meant that many of them ceased to operate (UNESCO, 2012). They further reported that as early as October 2012, only 10 months after the fall of Ben Ali, that government attacks on freedom of expression had resumed. In February 2012, Nasreddine Ben Saida, general director of Arabic daily newspaper Attounissia was the first journalist to be jailed since the revolution. While, as Layli Fouradi from Tunisian web magazine Inkyfada interviewed by Jon Alsop for an article in the Columbia Journalism Review in 2021 states, "Freedom of expression is one of the gains of the revolution in 2010... fear that once reigned has truly dissipated" (Allsop, 2021), there is no doubt there is an ongoing struggle to defend those gains. Reports such as one by Reuters in 2017 detailing efforts to use the "state of emergency that allows officials to curtail some rights in the name of national security" and a report that " 41 local and foreign journalists were beaten by police, harassed, insulted or treated aggressively" reveal the extent that government efforts to censor and intimidate the media continue ("Tunisia tightens restrictions," 2017). Alongside the abuses, legislative efforts to protect the media and widen participation are equally evident features of the post-revolution period.

In 2011, the National Authority of Information and Communication (INRIC) was set up by the interim government to assist in the freeing up of Tunisian media. Decree No. 10/2011 (2 March, 2011) was mandated to protect the Tunisian people's right to a free, diverse and fair media (Tunisian Government, 2011). Alongside the struggle for media reform and defence of the freedom of expression, sensitivity was shown to the question of the pluralism of voices. Recognising this, the Tunisian Constitution apportioned the entirety of Chapter 7 to "Local Authorities." Allocating a whole chapter of the constitution to discuss local governance has, in the same way as it did with the main traditional branches (executive, legislative, and judiciary), symbolically and literally conferred on the local authorities the explicit legal power to be the fourth branch in the constitutional authorities' arsenal.

Furthermore, within the space of a year of its establishment, INRIC had handed down a major report and had received applications for licenses from 74 radio and 33 television channels. On September 20, 2011, the Tunisian interior minister declared that 187 periodicals made up of dailies, weeklies, bi-monthlies, and magazines had obtained legal identification (Abou Arief, 2014; Touati, 2012, p. 146). Efforts to open broadcast media were, as stated by INRIC chair, Kamel Labidi, hampered by the combined acts of interference by media barons linked to the old regime and the governing party En Nahda's delaying tactics aimed to allow time to set up party-owned Islamist channels (Labidi, 2017, pp. 126-127). Cooperation among various civil society organisations paid off, and after almost a decade of campaigning, the Press Council was created in September 2020. The council's main purpose is to 
maintain self-regulation for different media outlets to protect freedom of the press and Tunisian citizens' right to access information (Miladi, 2021, p. 272).

Radio Tunisia, in 2021, reported that there are more than 70 Tunisian broadcasters, including public, private, associational, regional, and local broadcasters. Table 1 details the expansion of local broadcasting in Tunisian regions since the fall of Ben Ali.

Additionally, there were numerous electronic journals in Zarzis, Djerba, Medenine, and Tataouine. The Media Development Centre in Tunisia maintained that the north-western region in Tunisia, which entails four governorates-Kef, Siliana, Jendouba, and Bejadid not experience any associational or commercial broadcasts in comparison with the other regions in the country. What we can find in this region with its four states are some web-based broadcasts that were launched and have a significant online following. Although later on, the Tunisian ministry of youth and sport sponsored a project to support a broadcast in these governorates, these broadcasts usually transmit musical content (Moalla, 2019, pp. 18-19).

\section{Subtle Dynamics of Local Media Power: Harbingers of Change}

In the aftermath of the revolution, international development agencies, funders, as well as media reform experts quickly responded to the call for support of the democratic transition in Tunisia. They aimed to change the practices of Tunisian journalists, hoping to produce quality information. Within this framework, the African Center for the Development of Journalists and Communicators was created to support civil society and the democratic transition in Tunisia. The objectives of this group were to share information, promote synergies between support partners, and foster dialogue with national actors. The experience of associative media has met with enthusiasm from international actors who supported the idea on two levels: the capacity building and developing media structures through technical, logistic, as well as managerial support (Ammar, 2018, p. 6).

That helps to explain the variety of local community media launched after the revolution, especially after the foundation of the independent body responsible for reforming information and communication in postrevolution Tunisia. This organisation's laws were incentives for establishing different and varied media platforms in a country whose capital was the compass for the flow of information. In that respect, citizens found themselves in front of various communicational local outlets that talk about their youth unemployment, their stolen fortunes, and their martyrs. Although there were several private commercial broadcasts before the revolution, such as Express FM in Grand Tunis and Sfax, they were limited in terms of geographical extension. Moreover, they were largely considered mouthpieces of the ruling regime (Zran \& Sedraoui, 2019, p. 376).

Alongside a rise in the number of local platforms, there has been a qualitative shift as well. Under Ben Ali,

Table 1. Expansion of local community radio in Tunisia since the revolution.

\begin{tabular}{|c|c|c|}
\hline Region & Local Media Broadcaster & Date of Release \\
\hline Djerba & Ulysse FM & June 2012 \\
\hline Qabès & Oasis FM & December 2011 \\
\hline Gafsa & Sout EIManagem or Radio Mines FM & 8th February 2011 \\
\hline Tozeur, & Djerid FM & 18th April 2011 \\
\hline Kébili & Nefzawa net & 23rd July 2013 \\
\hline Kasserine & $\begin{array}{l}\text { Houna El Gassrine } \\
\text { Radio K-FM }\end{array}$ & $\begin{array}{l}\text { 12th March } 2012 \\
\text { 7th January } 2011\end{array}$ \\
\hline Sfax & DIWAN FM & 2013 \\
\hline Nabeul; & $\begin{array}{l}\text { Radio Med } \\
\text { Cap FM }\end{array}$ & $\begin{array}{l}\text { 27th April } 2015 \\
\text { 24th March } 2012\end{array}$ \\
\hline Kairouan & $\begin{array}{l}\text { Sabra FM } \\
\text { Dream FM (the city of Hajeb El Ayoun) }\end{array}$ & $\begin{array}{l}\text { 29th January } 2010 \\
\text { 6th April } 2014\end{array}$ \\
\hline Sousse 2011 to 2017 & $\begin{array}{l}\text { Nejma FM } \\
\text { Knooz FM } \\
\text { Msaken FM } \\
\text { MFM (serves Mahdia, Sousse and Monastir) } \\
\text { Jawhara FM }\end{array}$ & $\begin{array}{l}\text { 10th November } 2015 \\
\text { September } 2014 \\
2015 \\
\text { 2nd August } 2012 \\
\text { Created in } 2005 \text { then turned to serve the whole } \\
\text { country in } 2017\end{array}$ \\
\hline
\end{tabular}


local journalists who worked for international news agencies enjoyed some freedom of expression while being cautious about not transgressing editorial redlines set by Ben Ali's regime. These taboos were like investigating the deteriorating internal condition under Ben Ali, the latter's family corruption, wealth maldistribution, and the spread of poverty in the country (El-Issawi, 2012, p. 5). The ceiling of public liberties, especially in the media sphere, witnessed a boost and transformation that directly affected the topics the media could publish or broadcast. In that sense, we noticed that the editorial lines of the media delved into different topics and covered issues that were previously marked in the past as red line topics that no one should approach without permission from the centre. National media outlets were not entirely uncritical, but since they had been intertwined with the political and economic interests of those in power, they often failed to offer the fresh perspectives that people desired. In that respect, we highlight what was then a new turn in local community media that moved away from perpetuating the status quo to one that provided critical and fresh perspectives. This new approach was new not only for audiences and local authorities but also for the correspondents. In addition, many local broadcasters and their editorial teams adopted the new approach of pluralistic editorial lines that were free from any political, syndicalist, or social power pressures (El Bour, 2016, p. 3).

In other words, one characteristic of the postrevolution era has been an increase in the number of local community media providers and their role as the main source of information of regional matters for the national media still centred in Tunis. El Bour's field study in which she interviewed 16 local correspondents is indicative of this empowerment of local media in postrevolutionary Tunisia:

The working conditions today illustrate the new working environment. One notable change concerns the relationship with the regional power represented by the governor "when we cover protests and sit-ins, we give the citizens a voice and we go to the governor for the other story. When he refuses to comment... we report it." (El Bour, 2016, p. 8)

Local media proved its primacy in covering the different strikes and demonstrations that flooded the country after the 2011 Revolution in different cities and regions away from the capital Tunis. Furthermore, local platforms showed a high level of professionalism when covering the events of the Libyan wars that exploded on the Tunisian borders, providing centre-media with the required information on a daily basis that was on-time and live. This was especially the case for the Tataouine broadcast, which held the responsibility of reporting Libyan disputes that took place near the Tunisian borders (Zran \& Sedraoui, 2019, p. 385).

\section{Local Media: Opening Spaces for Minority Voices and Issues}

According to a survey run by Sigma Company in 2017 to measure the popularity of media platforms and broadcasts in Tunisia, local community media platforms were rated as very popular. In the southwest and southeastern regions of Sahel and Sfax, local community media broadcasts occupied higher positions above the centresponsored media. This was true everywhere except for the Northern area where the first private national radio station Mosaique FM is most popular. By examining audience statistics from the different broadcasters, it is evident that five out of eight regions demonstrate the supremacy of local media. In the three regions of Sfax, Gafsa, and Tataouine regional radio stations outperformed national and international broadcasters in audience share, with 170,000, 73,000 and 108,000, respectively. In most of these regions, private local or associational broadcasts ranked second most popular. Furthermore, among the six broadcasts that the survey covers, we notice a presence of some local regional broadcasts such as Diwan in Sfax, Nefzawa in southwest, as well as Oasis FM in Qabès (Open Sigma, 2017).

Before the revolution, national television transmitted programmes that centred on the capital and the national elites in Tunis, to the exclusion of regional actors. In so doing, they further marginalised the regions from national debate unless individuals travelled to the capital. Local media was partly responsible for changing a landscape that had largely been unresponsive to the needs of local populations. Minorities had no voice either. Since the revolution, there is evidence that this has changed. One example of the newfound space for minorities is the establishment of local media that represent the Amazigh people of Tunisia.

The creation of the Amazigh Nefzawa Journal and Radio Nefzawa has been an advance for minority rights in Tunisia. Prior to the revolution, Amazigh associations were banned, and any efforts to create an independent Amazigh voice were severely punished. Since the revolution, both platforms have been active in promoting the views and culture of the Amazigh people. Both the journal and the radio station ran stories on both the defence of Amazigh language, which is not recognised as an official language of Tunisia, and Amazigh culture more broadly. Radio Nefzawa declares its mission is to be a voice for baladeyaty (Arabic for "my land") and to act as a channel between the region and the state. One of the most interesting and revealing findings from the analysis of the content of Radio Nefsawa was the extent that local issues of underdevelopment were evident. In the period from 2016, we found regular stories and programs focused on local underdevelopment, poverty, unemployment, and the environment. This is evidence of what Badran et al. (2021, p. 2) argue is where the local community media have also "contributed to re-centring issues of (regional) inequality." 
Since the revolution, Radio Mines FM has run extensive coverage of the revolt in the Gafsa mining basin. Strikes in the mining region of southwestern Tunisia, which consists of four cities-Mdhilla, Redeyef, Moularès, and Métlaoui-intensified in 2008, leading to a crackdown by the government. All of these cities are administered under the Gafsa governorate that lies 350 kilometres southwest of Tunis. Starting in 2008, strikes in Gafsa occurred in January each year. However, despite the significance of these strikes, prior to the revolution, little attention was paid to them by the government-controlled Tunisian media. However, the creation of local media in Gafsa has allowed the issues of the mining communities to be voiced both locally and nationally in ways that were not possible before the revolution.

After the revolution, activists such as Nour Eddin Hani, who is a member of the local civil society in Gafsa, were able to use the newly emergent local media in ways that were not previously possible. Hani (Afdal, 2016) and his comrades were optimistic after the revolution that their demands would be heard, and that the government would respond. One of the main features of local media after January 2011 is its tendency to create new interactional relationships with local, civil, syndicalist, and political actors. Such relationships have been vertical for a long time prior to January 2011. In more recent years, local community media has been responsible for connecting politics in the regions with politicians in Tunis. A response did eventually come. The local representative of the Islamic movement and leading party in the Parliament En Nahda, Reda Samauiy, responded to the heated situation in the area in 2016 and met with some of the protesters. Also, the local representative of the Popular Front, Habib Tabasi, was able to utilise local media to connect the several waves of protests in this area due to its problems of poverty and unemployment (Afdal, 2016).

Our analysis of the four local media supports the claim that events arising from local communities reached unprecedented levels, and that this newly flourishing landscape has changed people's lives in a number of ways (Mezghanni, 2015, pp. 205-207; Zran \& Sedraoui, 2019, p. 381). Radio Gafsa and Radio Nefzawa transmit stories by women for women. Indeed both stations have a notable number of female reporters and broadcasters presenting news and other programs. Our research also demonstrates that they are all communicating national and international news to their local communities from their own perspective. Local actors are now translating and interpreting national and international events through local perspectives and positions. In turn, this allows local community media to articulate what local communities feel, aspire, and believe in a limited geographical space.

\section{Conclusion: Local Community Media and the Future of Tunisian Democracy}

In this article, we have analysed the local media kaleidoscope in Tunisia. Tunisia witnessed a democratic transition where local community media platforms have come to play a role in fostering the democratic transition, shedding light on local communities' situations and demands as they represent the core element of any real democracy. Democracy is at a crossroads everywhere, including in Tunisia. For many scholars of democracy, it is no coincidence that media is also facing a watershed moment. Corporatisation, financial crisis, the phenomenal changes attributable to digitalisation, and increasing authoritarianism are all factors that impact democracy and the state of media.

Tunisia has not been immune to these forces and, at the same time, the 2011 revolution unleashed pentup frustrations and mobilised strong democratic trends that have pushed back to ensure that the authoritarianism, government repression, and censorship do not whittle away the hard-won freedoms of 2011. The national media in Tunisia has not entirely broken free of its past close connections to the political and business elite who have bought into the democratic transition only as far as "the more things change, the more they stay the same." The extent that the national media, then, contributes to the democratic transition is uncertain given that, as Farmanfarmaian (2014) has said, the "power of media barons is immense." However, as this article has argued, local community media in Tunisia demonstrates the potential of local community media to empower local communities and promote democratisation.

Local media in Tunisia is not without its own challenges. Poorly funded, often reliant on volunteer labour and faced with pressure from the age of the internet, local media exist on the precipice. Yet, as the data from the Open Sigma survey illustrates, and our analysis of local media content demonstrates, local media in regional parts of Tunisia are popular and provide a platform for articulating the daily struggles for recognition and relevance of people in the peripheries of the country. This aspect of local media may serve to further the democratic transformation in a country in transition as much as, or more than, parliaments and national elections in an era where political and economic elites have captured the institutions of the demos (Fraser, 2020).

The future of Tunisian democracy and Tunisia's fledging local community media is uncertain. What is more certain is that the fate of both is intertwined. As globalisation, especially the Anglo-American model that emerged from the Cold War, is seen as the only alternative, and national institutions are tainted with, or captured by, authoritarianism - the local level might be the site where democracy is to be saved. As this article has shown, in Tunisia, at least, one vehicle to promote and defend democracy under assault is local community media. 


\section{Conflict of Interests}

The authors declare no conflict of interest.

\section{Disclaimer}

The Arab-German Young Academy of Sciences and Humanities (AGYA) is supporting the thematic issue "Ten Years after the Arab Uprisings: Beyond Media and Liberation," edited by AGYA alumna Hanan Badr (Gulf University of Science and Technology, Kuwait) and AGYA member Lena-Maria Möller (Max Planck Institute for Comparative and International Private Law, Germany). AGYA is funded by the German Federal Ministry of Education and Research (BMBF). The authors remain solely responsible for the content and recommendations provided in this publication, which do not reflect the positions of AGYA or any of its funding partners.

\section{References}

Abou Arief, N. (2014). Ealam alqourb yatabalouar fe Tounis [Proximity media crystalises in Tunisia]. The Danish-Arab Partnership Programme. https://bit.ly/ $3 \ln Y p E R$

Abueish, T. (2021, July 29). Nationwide poll finds 87 pct of Tunisians support President Saied's decisions. Al Arabiya Network. https://english.alarabiya.net/ News/north-africa/2021/07/29/Nationwide-pollfinds-87-pct-of-Tunisians-support-President-Saieds-decisions

Adsera, A., Boix, C., \& Payne, M. (2003). Are you being served? Political accountability and quality of government. The Journal of Law, Economics and Organization, 19(2), 445-490.

Afdal, R. (2016, January 26). AlHirak fe Tounis: Gafsa tantafed fe zekra ehtegag al houd al mandjami [Social movement in Tunisia: Gafsa revolts in the anniversary of mining basin protests]. Al Arabi AlDjadid. https:// www.alaraby.co.uk

Akhtar, A. (2019). Losing the news: The decimation of local journalism and the search for solutions. PEN America.

Allsop, J. (2021, January 19). Press freedom and the Arab Spring, ten years on. Columbia Journalism Review. https://www.cjr.org/the_media_today/ arab_spring_press_freedom_10_years.php

Ammar, S. (2018). L'émergence des radios associatives dans une Tunisie en transition démocratique [The emergence of community radios in a Tunisia in democratic transition]. Radio Morphoses [En Ligne], 3, 1-11.

Badran, Y., \& Loisen, J., \& Smets, K. (2021). Local associative media in Tunisia and the value of voice. The Journal of North African Studies. Advance online publication. https://doi.org/10.1080/13629387.2021. 1878888

Birowo, M. A. (2011). Community radio and empowerment of local culture in Indonesia. In K. Sen \& D.
Hill (Eds.), Politics and the media in twenty-first century Indonesia: Decade of democracy (pp. 49-66). Routledge.

Bogart, L. (1998). Media and democracy. In E. E. Dennis \& R. W. Snyder (Eds.), Media and democracy (pp. 3-12). Transaction.

Buckley, S., Chaabi, S., \& Ouarda, B. (2013). The assessment of media development in Tunisia based on the UNESCO media development indicators. UNESCO; IPDC. http://www.unesco.org/new/ fileadmin/MULTIMEDIA/HQ/Cl/Cl/pdf/IPDC/tunisia_ mdi_report_english.pdf

Carpenter, N., Lie, R., \& Servaes, J. (2003). Community media: Muting the democratic media discourse? Continuum: Journal of Media and Cultural Studies, 17(1), 51-68.

Cherni, N. (2014). The Tunisian media in transition: From manufacturing consent to manufacturing "discontent." In M. Ennaji (Ed.), Multiculturalism and democracy in North Africa: Aftermath of the Arab Spring (pp. 176-200). Routledge.

Dennis, E. E., \& Snyder, R. W. (1998). Introduction. In E. E. Dennis \& R. W. Snyder (Eds.), Media and democracy (pp. xv-xix). Transaction.

El Bour, H. (2016). Être correspondant régional en Tunisie: De l'aliénation au pouvoir à la liberté totale [Being a regional correspondent in Tunisia: From alienation of power to total freedom]. L'Année du Maghreb, 15, 1-15.

El-Issawi, F. (2012). Tunisian media in transition. Carnegie Endowment for International Peace.

Farmanfarmaian, R. (2014). What is public, what is private, and who exercises media power in Tunisia? A hybrid-functional perspective on Tunisia's media sector. The Journal of North African Studies, 19(5), 656-678.

Fraser, N. (2020). The old is dying and the new cannot be born: From progressive neoliberalism to Trump and beyond. Verso.

Ghazali, A. (2015). Assessment of media legislation in Tunisia. Med Media Project.

Hayes, D., \& Lawless, J. (2015). As local news goes, so does citizen engagement: Media, knowledge and participation in US House elections. The Journal of Politics, 77(2), 447-462.

Hayes, D., \& Lawless, J. (2018). The decline of local news and its effects: New evidence from longitudinal data. The Journal of Politics, 80(1), 332-336.

Hess, K., \& Waller, L. (2016). Rethinking news media and local government: Journalism, politics and symbolic power. Australian Journalism Review, 38(2), 5-17.

Homid, S. (2012). Dour al ezaat al mahaleyyah fe tarseekh mafhoum al wehda al wataneya [Local community's broadcasting in consolidating national unity conception]. AlManhal.

Howley, K. (2005). Community media: People, places, and communication technologies. Cambridge University Press. 
Howley, K. (2013). Community media studies: An overview. Communication and Media, 7(10), 818-828.

Keane, J. (1991). The media and democracy. Polity Press.

Keane, J. (2011, April 28). Refolution in the Arab world. openDemocracy. https://www.opendemocracy.net/ en/refolution-in-arab-world

Keane, J. (2013). Democracy and media decadence. Cambridge University Press.

Kenny, P. (2019). The enemy of the people. Political Research Quarterly, 73(2), 261-275.

Labidi, K. (2017). Tunisia's media barons wage war on independent media regulation. In A. Schiffrin (Ed.), In the service of media power: Media capture and the threat to democracy (pp. 125-135). Center for International Media Assistance; National Endowment for Democracy.

Leupold, A., Klinger, U., \& Jarren, O. (2018). Imagining the city: How local journalism depicts social cohesion. Journalism Studies, 19(7), 960-982.

Lynch, M. (2015). After the Arab Spring: How the media trashed the transitions. Journal of Democracy, 26(4), 90-99.

Manyozo, L. (2012). Media, communication and development: Three approaches. SAGE.

McChesney, R. W. (1997). Corporate media and the threat to democracy. Seven Stories Press.

Meijer, I. (2010). Democratizing journalism: Realising the citizen's agenda for local news media. Journalism Studies, 11(3), 327-342.

Mezghanni, S. (2015). Taazeez al mowatanah men khelal al modjtama al madani wash sharakat al elameya: Halat al ezaat al mahaleyah [Fostering citizenship through civil society and media corporations: Local radios as a case study]. In L. Hajji (Ed.), Al ealam fe marahel al enteqal as-seyasy: Al halah at Tounesia namozadjan [Media in political transitional times: Tunisian case as an example] (pp. 183-212). Arab Scientific Publishers.

Miladi, N. (2021). Tunisia: The transformative media landscape after the revolution. In C. Richter \& C. Kozman (Eds.), Arab media systems (pp. 267-285). Open Book.

Moalla, A. (2019). Kharetat al mashhad al ealami bel shamal al gharbi at-Tounsi [The media landscape in north-western Tunisia]. Media Development Centre.

Mughan, A., \& Gunther, R. (2000). The media in democratic and nondemocratic regimes: A multilevel perspective. In R. Gunther \& A. Mughan (Eds.), Democracy and the media: A comparative perspective (pp. 1-27). Cambridge University Press.

Nielsen, R. K. (2015). Introduction: The uncertain future of local journalism. In R. K. Nielsen (Ed.), Local journalism: The decline of newspapers and the rise of digital media (pp. 1-30). I.B. Tauris.

Open Sigma. (2017). Audiences radio: Faire parler les chiffres [Radio audiences: Making the numbers talk]. http://www.tekiano.com/wp-content/
uploads/2017/01/Bilan-m\%C3\%A9dias-2016-etperspectives-du-march\%C3\%A9-2017-en-Tunisieaudience-radio.pdf

Phelan, S. (2014). Neoliberalism, media and the political. Palgrave Macmillan.

Pope. K. (2018, July 23). Who suffers when local news disappears. Columbia Journalism Review. https://www.cjr.org/business_of_news/new-yorkdaily-news.php

Reporters Without Borders. (2021). RSF 2021 index: Covid-19, latest ailment to afflict Middle East's moribund media. https://rsf.org/en/rsf-2021-indexcovid-19-latest-ailment-afflict-middle-eastsmoribund-media

Repucci, S. (2019). Freedom and the media 2019: A downward spiral. Freedom House. https://freedom house.org/report/freedom-and-media/2019/mediafreedom-downward-spiral

Saeed, S. (2009). Negotiating power: Community media, democracy, and the public sphere. Development in Practice, 19(4/5), 466-478.

Smati, N. (2010). La presse régionale en Tunisie: Une presse de territoire marginalisée [The regional press in Tunisia: A press from marginalized territory]. Horizons Maghrébins-Le droit àla mémoire, 62(1), 12-22.

Snyder, J., \& Stromberg, D. (2010). Press coverage and political accountability. Journal of Political Economy, 118(2), 355-354.

Springborg, R. (2007). The Middle East's democracy gap: Causes and consequences. The Brown Journal of World Affairs, 13(2), 233-245.

Touati, Z. (2012). Presse et révolution en Tunisie: Rôle, enjeux et perspectives [Press and revolution in Tunisia: Role, challenges and perspectives]. ESSACHESS: Journal for Communication Studies, 5(1/9), 140-150.

Tunisia tightens restrictions on journalists, press freedom at risk-union. (2017, April 12). Reuters. https://www.reuters.com/article/us-tunisiapolitics-censorship-idUSKBN17D1RQ

Tunisian Government. (2011). Ihdath hayyat wataniat mustaqilat li'iislah al'iielam wal Itisal [Creation of an independent national authority for media and communication reform] (Decree No. 10/Year 2011).

UNESCO. (2012). UNESCO supports community radio in Gafsa. https://reliefweb.int/report/tunisia/unescosupports-community-radio-gafsa

Voltmer, K. (2013). The media in transitional democracies. Polity Press.

Zaid, B. (2018). A normative study of broadcast regulators in the Arab World. International Journal of Communication, 12, 4401-4420.

Zayani, M. (2015). Networked publics and digital contention: The politics of everyday life in Tunisia. Oxford University Press.

Zemni, S. (2021, March 16). Tunisia's marginalized redefine the political. Middle East Research and Infor- 
mation Project. https://merip.org/2021/03/tunisiasmarginalized-redefine-the-political

Zran, J., \& Sedraoui, N. (2019). Allelam wal enteqal addemoqraty fe Tounis: Mena al ielam al djahawy al markazy ela al ielam almahali al mohawkam [Media and democratic transition in Tunisia: From central regional media to governed local meida]. In J. Zran \&
N. Miladi (Eds.), Allelam wal enteqal addemoqraty fel alam al Arabi: Bedayat nehayat al estethnaa al Arabi [Media and democratic transition in Arab world: The beginning of the end of Arab exceptionalism] (pp. 369-393). Sotumedias; Arab Media \& Communication Network.

\section{About the Authors}

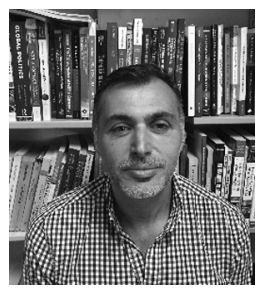

Noah Bassil is associate professor of politics and international relations. His intellectual work focuses on the structural and systemic legacies of colonialism and neoliberal capitalism as the basis for understanding contemporary politics. Historical analysis is the foundation on which he explained the conflict in Darfur, Sudan that broke out in the early 2000s and other more recent events in the Arab states of North Africa and Asia.

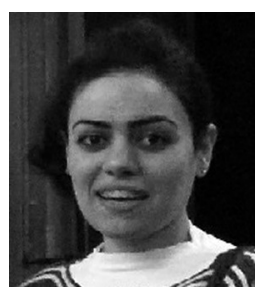

Nourhan Kassem is a political science cotutelle doctoral student across Macquarie University, Australia, and Giessen University, Germany. Her academic foci are religiopolitical studies, how religion affects its society structurally and systematically, and its position in national and international systems characterised by neoliberalism. Discourse analysis was the basis on which she explored Khomeini's conceptualisation of state and Velayat-e Faqih (Guardianship of Jurists), a concept that spread outside its national boundaries. 